\title{
PENGARUH PENGETAHUAN DASAR EKONOMI DAN PERSEPSI LINGKUNGAN PONDOK PESANTREN TERHADAP POLA KONSUMSI SANTRIWAN IIS MA PONDOK PESANTREN NURUL ULUM MALANG.
}

\author{
Mohaswin Rizki Ilham ${ }^{1}$, Sapir $^{2}$ \\ 1. Economic Education Program, Faculty of Economics, State University Malang \\ 2. Economic Education Program, Faculty of Economics, State University Malang \\ aswinkikik08@gmail.com, sapir.fe@um.ac.id
}

\begin{abstract}
Education in boarding schools having own way educate school tuition or of the so-called santri, santri learned about general studies and live a daily lives in the neighborhood pondok pesantren .Consumption patterns in boarding schools influenced by many factors such as knowledge basic economic, and environment boarding schools. Population in research it is a whole santriwan IIS MA Pondok Pesantren Nurul Ulum poor were 57 santriwan. Sample in this research using all population. The kind of research that is used is research eksplanasi, with technical linear regression analysis worship of idols .Variable research among other: the economics basic knowledge $\left(\mathrm{X}_{1}\right)$, perception of boarding school $\left(\mathrm{X}_{2}\right)$, and consumption behavior $(\mathrm{Y})$. Using techniques data collection tests and survey or questionnaire. The conclusion of research is (1) basic knowledge economy influential significantly to consumption patterns santriwan IIS MA boarding schools Nurul Ulum Malang. (2) boarding schools environmental effect significantly to consumption patterns santriwan IIS MA boarding schools Nurul Ulum Malang. Basic knowledge economy and the environment boarding schools significant against consumption patterns santriwan IIS MA boarding schools Nurul Ulum Malang. Because of that, Expected the boarding schools able to guide santriwan for better again in consumption.
\end{abstract}

Keywords: Consumption Behavior, Economics Basic Knowledge, and Perception of Boarding School

History of Article:

Received : (12 July 2017), Accepted : (19 September 2017), Publised: (15Oktober 2017)

Citation:
Ilham, Mohaswin Rizki, \& Sapir (2017) Pengaruh Pengetahuan Dasar Ekonomi Dan Persepsi
Lingkungan Pondok Pesantren Terhadap Pola Konsumsi Santriwan IIS Ma Pondok Pesantren Nurul
Ulum Malang.[The Influence of Economic Basic Knowledge and Perception of Islamic boarding
School Environment to (Islamic) Senior High School Student of IIS Nurul Ulum Islamic Boarding
School Malang]. Jurnal Pendidikan Ekonomi, 10(2), 137-146

(C) Universitas Negeri Malang

Jurnal Pendidikan Ekonomi

p-ISSN: 0216-7085, e-ISSN: 2579-3780 


\section{PENDAHULUAN}

Kegiatan untuk membelanjakan penghasilan atau pendapatan untuk berbagai barang atau jasa guna memenuhi kebutuhan sehari hari disebut konsumsi. Kegiatan konsumsi yang paling penting bagi manusia adalah memenuhi kebutuhan pokok.

Perkembangan jaman yang semakin maju dan modern berdampak pula bertambahnya pilihan untuk berkonsumsi, terutama untuk kebutuhan pokok. Dalam hal ini usia remaja mudah terpengaruh untuk lebih banyak berkonsumsi karena mengikuti tren saat ini. Dalam membeli suatu produk konsumen tidak hanya didasari oleh pertimbangan manfaat dari produk itu melainkan kepuasan lain yang diharapkan oleh konsumen. Kondisi seperti ini didasari pada keinginan tanpa di imbangi dengan kebutuhan dan financial yang dimiliki.

Pengetahuan dan pemahaman atas konsep keuangan (financial) yang digunakan untuk membuat pilihan keuangan yang efektif (Pisa, 2012) ini, akan dapat meningkatkan financial well-being dari individu dan kelompok serta untuk berpartisipasi dalam kehidupan ekonomi.

Ekonomi sebagai mata pelajaran di MA diharapkan mampu memberikan bekal kepada santri untuk bersikap rasional dan ekonomis dalam melakukan tindakan ekonomi sekarang dan massa akan datang. Rosyidi (2006: p. 8) mengemukakan bahwa " ilmu ekonomi adalah salah satu cabang ilmu pengetahuan yang berdaya upaya untuk memberikan pengetahuan dan pengertian tentang gejala-gejala masyarakat yang timbul karena perbuatan manusia dalam usahanya untuk memenuhi kebutuhan atau untuk mencapai kemakmuran" Pengetahuan santri mengenai ekonomi dapat dilihat dari bagaimana dia mengaplikasikan apa yang dia pelajari kedalam kehidupan sehari-hari agar menjadi konsumen yang produktif dalam berkonsumsi.

Santri yang memiliki pengetahuan terhadap ekonomi diharapkan memiliki pola konsumsi yang rasional, artinya santri harus dapat membedakan kebutuhan dan keinginan sehingga tidak menggunakan pendapatan yang diterima untuk mengkonsumsi barang yang kurang dibutuhkan dan juga memiliki pola konsumsi rasional mereka juga akan menjadi pelaku ekonomi yang produktif (Mankiw, 2012). Lingkungan belajar yang baik akan mempengaruhi kegitan santri untuk beraktivitas sehari hari, aktivitas santri dalam belajar dapat mengendalikan konsumsi yang tidak rasional.

Kesibukan dan keaktifan santri ketika belajar berpengaruh terhadap keinginan berkonsumsi yang tidak rasional karena waktu sangat dimanfaatkan untuk belajar. Pondok Pesantren Nurul Ulum merupakan lembaga pendidikan Agama Islam di Kota Malang yang sudah memiliki sekolah formal di dalam pembelajaranya. Santri tidak hanya menerima pembelajaran tentang ilmu agama dan akhlak melaikan pendidikan yang setara dengan pendidikan formal diluar (Dhofier, 2015)

Pondok Pesantren Nurul Ulum memiliki Madrasah Aliyah di dalam pondok pesantren sehingga santri menerima pembelajaran ilmu ekonomi. Santri yang paham tentang ilmu ekonomi dan memanfaatkan lingkungan belajar di dalam pondok pesantren dengan baik diharapkan dapat memiliki pola konsumsi yang rasional . Dari latar belakang di atas, penulis tertarik untuk melakukan penelitian berhubungan dengan faktor yang mempengaruhi pola konsumsi santriwan. Peneliti ingin melakukan penelitian dengan judul "Pengaruh Pengetahuan Dasar Ekonomi dan Persepsi Persepsi 
Lingkungan Pondok Pesantren Terhadap Pola Konsumsi Santriwan IIS MA Pondok Pesantren Nurul Ulum Malang".

\section{METODE PENELITIAN}

Penelitian ini menggunakan pendekatan penelitian kuantitatif. Karena data penelitian berupa angka dan analisis data menggunakan statistik. Penelitian ini merupakan jenis penelitian deskriptif kondisional untuk menentukkan ada tidaknya pengaruh, dan jika ada pengaruh seberapa besar pengaruh variabel bebas yaitu pengetahuan ekonomi $\left(\mathrm{X}_{1}\right)$, persepsi lingkungan pondok pesantren $\left(\mathrm{X}_{2}\right)$, terhadap variabel terikat pola konsumsi santriwan (Y). Penelitian ini difokuskan pada: pertama, pengaruh secara parsial variabel bebas 1 (pengetahuan dasar ekonomi $/ \mathrm{X}_{1}$ ) terhadap variabel terikat (pola konsumsi/Y). Kedua, pengaruh secara parsial variabel bebas 2(persepsi lingkungan pondok pesantren $/ \mathrm{X}_{2}$ ) terhadap variabel terikat (pola konsumsi/Y). Ketiga, pengaruh secara simultan variabel bebas (pengetahuan dasar ekonomi $/ \mathrm{X}_{1}$ dan persepsi lingkungan pondok pesantren $/ \mathrm{X}_{2}$ ) terhadap variabel terikat (pola konsumsi/Y).

\section{Populasi dan Sampel}

Populasi dalam penelitian ini adalah siswa kelas XI IIS di SMA Panjura Malang dengan jumlah populasi 152 siswa dari 4 kelas. Teknik pengambilan sampel dalam penelitian ini adalah proporsional random sampling. Teknik proporsional random sampling merupakan teknik pengambilan sampel yang diperoleh secara acak dari subyek-subyek populasi yang diteliti dan sesuai dengan ukuran unit sampling yang seimbang atau sebanding dengan banyaknya subyek masing-masing kelompok. Penelitian ini menggunakan rumus Slovin untuk menentukan ukuran sampel dari suatu populasi. Penelitian ini, penulis menetapkan pengambilan sampel yaitu dengan e sebesar 5\% dari jumlah populasi siswa kelas XI IIS SMA Panjura Malang sehingga banyaknya sampel dalam penelitian ini 111 siswa. Populasi dalam penelitian ini adalah keseluruhan santriwan jurusan IIS MA Nurul Ulum Malang yang berjumlah 57 santri. Pemilihan santriwan jurusan IIS sebagai populasi dikarenakan konsentrasi jurusan tersebut lebih mengarah pada studi ekonomi yang relevan dengan penelitian. Penelitian ini menggunakan sampel populasi karena jumlah santriwan yang akan diteliti adalah 57 santriwan, sehingga penelitianya menggunakan penelitian populasi. Sampel penelitian yang diambil adalah seluruh santriwan IIS MA Pndok Pesantren Nurul Ulum.

\section{Instrumen Penelitian}

Instrumen yang digunakan penelitian untuk pengambilan data dengan kuisioner dan tes. Instrumen pengambilan data dengan kuisioner berkaitan dengan variabel persepsi lingkungan pondok pesantren dan pola konsumsi diisi oleh santri. Sedangkan instrumen pengambilan data dengan tes berkaitan dengan variabel pengetahuan dasar ekonomi diisi oleh santri.

\section{Pengumpulan Data}

Pemerolehan data mengenai persepsi lingkungan pondok pesantren dan pola konsumsi peneliti menggunakan instrumen angket. Penyebaran angket dilakukan kepada 57 santriwan IIS di MA Pondok Pesantren Nurul Ulum Malang yang menjadi 
sampel penelitian. Pengisian angket oleh santriwan dilakukan pada jam pelajaran secara bergantian untuk masing masing kelas tapi tetap dalam jangka waktu satu hari. Tes dalam penelitian ini bertujuan untuk mengetahui kemampuan siswa dalam menyerap mata pelajaran ekonomi yang terbatas pada pola konsumsi. tes diberikan kepada 57 santriwan IIS di MA Pondok Pesantren Nurul Ulum Malang yang menjadi sampel penelitian. Tes dikerjakan santriwan pada saat jam pelajaran secara bergantian untuk masing masing kelas tapi dalam jangka waktu satu hari..

Analisis Data

Analisis statistik deskriptif digunakan untuk menganalisis data dengan cara mendeskripsikan atau menggambarkan data yang telah terkumpul sebagaimana adanya tanpa bermaksud membuat kesimpulan yang berlaku untuk umum atau generalisasi. Penelitian menggunakan teknik analisis presentase. Pada teknik presentase mencari panjang kelas interval

\section{HASIL DAN PEMBAHASAN}

\section{Deskripsi Data Pengetahuan Dasar Ekonomi santriwan}

Tabel 1. Distribusi Frekuensi Variabel Pengetahuan Dasar Ekonomi

\begin{tabular}{lllll}
\hline No & Klasifikasi & Interval & Jumlah & Persentase \\
\hline 1 & Tinggi & $10-20$ & 44 & $77,1 \%$ \\
2 & Rendah & $0-9$ & 13 & $22,9 \%$ \\
& & & & $100 \%$ \\
\hline
\end{tabular}

Berdasarkan tabel 1 di atas dengan alasan bahwa santriwan yang memiliki tingkat pengetahuan dasar ekonomi tinggi pada kategori tinggi sebesar 44 santriwan dengan presentase $77.1 \%$ dan 13 santriwan memiliki pengetahuan dasar ekonomi pada kategori rendah dengan presentase $22.3 \%$. Sehingga dapat disimpulkan bahwa tingkat pengetahuan dasar ekonomi santriwan IIS MA Pondok Pesantren Nurul Malang tinggi..

Persepsi Lingkungan Pondok Pesantren

Tabel 2 Distribusi Frekuensi Variabel Persepsi lingkungan pondok pesantren

\begin{tabular}{lllll}
\hline No & Klasifikasi & Interval & Jumlah & Persentase \\
\hline 1 & Sangat Tinggi & $63-70$ & 19 & $33,33 \%$ \\
2 & Tinggi & $51-62$ & 28 & $49,12 \%$ \\
3 & Cukup & $39-50$ & 10 & $17,54 \%$ \\
4 & Rendah & $27-38$ & 0 & $0,00 \%$ \\
5 & Sangat Rendah & $15-26$ & 0 & $0,00 \%$ \\
& Total & $\mathbf{7 0}$ & $\mathbf{5 7}$ & $\mathbf{1 0 0 \%}$ \\
\hline
\end{tabular}


Berdasarkan tabel 2 diatas dapat diketahui bahwa mayoritas anggapan santriwan terhadap persepsi lingkungan pondok pesantren pada klasifikasi tinggi pada interval 51-62 yaitu 28 santriwan dengan presentase 49,19\%. Sedangkan minoritas anggapan santriwan terhadap persepsi lingkungan pondok pesantren pada klasifikasi sangat cukup pada interval antara 39-50 yaitu 10 santriwan dengan presentase (17.54\%).

\section{Pola Konsumsi Santriwan}

Tabel 3 Distribusi Frekuensi Pola Konsumsi Santriwan

\begin{tabular}{lllll}
\hline No & Klasifikasi & Interval & Jumlah & Persentase \\
\hline 1 & Sangat & $63-70$ & 3 & $5,26 \%$ \\
& Tinggi & & & \\
2 & Tinggi & $51-62$ & 31 & $54,38 \%$ \\
3 & Cukup & $39-50$ & 22 & $38,59 \%$ \\
4 & Rendah & $27-38$ & 1 & $1,75 \%$ \\
5 & Sangat & $15-26$ & 0 & $0,00 \%$ \\
& Rendah & & & $\mathbf{1 0 0 \%}$ \\
& Total & $\mathbf{7 0}$ & $\mathbf{5 7}$ & \\
\hline
\end{tabular}

Berdasarkan tabel 3 diatas dapat diketahui bahwa mayoritas santriwan memiliki pola konsumsi pada klasifikasi tinggi pada interval 51-62 yaitu 31 santriwan dengan presentase $54.38 \%$. Sedangkan minoritas santriwan memiliki pola konsumsi pada klasifikasi sangat tinggi pada interval 27-38 yaitu 1 santriwan dengan presentase 1,75.

\section{Uji Normalitas}

Tabel 4 Hasil Uji Normalitas Data

\begin{tabular}{ll}
\hline Variabel & Asymp. Sig. (2-tailed) \\
\hline 1. $\left(\mathrm{X}_{1}\right)$ & .675 \\
2. $\left(\mathrm{X}_{2}\right)$ & .487 \\
3. $(\mathrm{Y})$. & .679
\end{tabular}

Berdasarkan tabel 4 dapat disimpulkan bahwa data penelitian berdistribusi normal. Hal ini dapat dilihat dari nilai probabilitas (Asymp.Sig) dengan probabilitas siginifikasi variabel X1 (pengetahuan dasar ekonomi) sebesar 0.675. Nilai probabilitas signifikansi variabel X2 (persepsi lingkungan pondok pesantren) sebesar 0.487. Sedangkan nilai probabilitas signifikansi untuk variabel Y (pola konsumsi) adalah 0.679. Nilai signifikansi ke tiga variabel >0,05. Dengan demikian dapat disimpulkan bahwa data dalam penelitian ini memenuhi uji normalitas data.

Uji Multikolinearitas

Tabel 5 Hasil Uji Multikolinearitas

\begin{tabular}{lll}
\hline Variabel & Tolerance & VIF \\
\hline$\left(\mathrm{X}_{1}\right)$ & .953 & 1.050 \\
$\left(\mathrm{X}_{2}\right)$ & .953 & 1.050 \\
& & \\
\hline
\end{tabular}


Data yang diperoleh pada tabel 5 menunjukkan bahwa nilai Tolerance kedua variabel $>0,1$ yaitu sebesar 0,953 dan nilai VIF $<10$ yaitu sebesar 1.050. Dengan demikian dapat disimpulkan bahwa tidak terjadi multikolinearitas antara variabel bebas.

\section{Uji Heterokedastisitas}

\section{Tabel 6 Hasil Uji Heterokedastisitas}

\begin{tabular}{ll}
\hline Variabel & Sig. \\
\hline$\left(\mathrm{X}_{1}\right)$ & 1.000 \\
$\left(\mathrm{X}_{2}\right)$ & 1.000 \\
\hline
\end{tabular}

Berdasarkan tabel 6 data diperoleh bahwa masing-masing variabel penelitian nilai sig $>0.05$ yaitu variabel X1 (pengetahuan dasar ekonomi) sebesar 1.000 dan variabel X2 (persepsi lingkungan pondok pesantren) sebesar 1.000. Dengan demikian dapat disimpulkan bahwa model regresi dalam penelitian ini tidak terjadi heterokedastisitas.

\section{Uji Hipotesis}

Ujit

Tabel 7 Hasil Uji t

\begin{tabular}{ll}
\hline Variabel & Sig. \\
\hline$\left(\mathrm{X}_{1}\right)$ & .001 \\
$\left(\mathrm{X}_{2}\right)$ & .000 \\
\hline
\end{tabular}

Berdasarkan tabel 7 dapat diketahui bahwa variabel pengetahuan dasar ekonomi santriwan (X1) memiliki nilai sig.t $<$ alpha yaitu sebesar $0.001<0.05$. Apabila Sig. $t<$ alpha, maka nilai hipotesis nol (H0) ditolak dan hipotesis alternatif (Ha) tidak ditolak. Dengan demikian dapat disimpulkan bahwa terdapat pengaruh yang signifikan antara pengetahuan dasar ekonomi santriwan (X1) terhadap pola konsumsi (Y) santriwan IIS MA Pondok Pesantren Nurul Ulum Malang.

Berdasarkan tabel 7 dapat diketahui bahwa variabel Persepsi lingkungan pondok pesantren $(\mathrm{X} 2)$ memiliki nilai sig.t $<$ alpha yaitu sebesar $0.000<0.05$. Apabila Sig. $\mathrm{t}<$ alpha, maka nilai hipotesis nol (H0) ditolak dan hipotesis alternatif (Ha) tidak ditolak. Dengan demikian dapat disimpulkan bahwa terdapat pengaruh yang signifikan antara Persepsi lingkungan pondok pesantren (X2) terhadap pola konsumsi (Y) santriwan IIS MA Pondok Pesantren Nurul Ulum Malang

\section{Uji F}

Tabel 8 Hasil Uji F

\begin{tabular}{llll}
\hline Model & F & Sig. \\
\hline 1 & $\begin{array}{l}\text { Regression } \\
\text { Residual } \\
\text { Total }\end{array}$ & 21.756 & $.000^{\mathrm{b}}$ \\
\hline
\end{tabular}

Berdasarkan tabel 8 diketahui bahwa signifikansi $\mathrm{F}$ sebesar 0.000 dan $\mathrm{F}_{\text {hitung }}$ sebesar 21.756. Nilai signifikansi $F<0,05$ sehingga hipotesis nol ditolak dan hipotesis 
alternatif tidak ditolak. Dengan demikian dapat disimpulkan bahwa $\mathrm{H}_{0}$ dalam penelitian ini ditolak dan $\mathrm{H}_{\mathrm{a}}$ tidak ditolak yang berarti terdapat pengaruh yang signifikan antara pengetahuan dasar ekonomi $\left(\mathrm{X}_{1}\right)$ dan persepsi lingkungan pondok pesantren $\left(\mathrm{X}_{2}\right)$ terhadap pola konsumsi (Y) santriwan IIS MA Pondok Pesantren Nurul Ulum Malang.

\section{Analisis Data dalam Regresi Berganda}

$Y=a+\beta_{1} X_{1}+\beta_{2} X_{2}+e$

$\mathrm{Y}=17.297+0.812 \mathrm{X}_{1}+0.451 \mathrm{X}_{2}+\mathrm{e}_{\mathrm{i}}$

Persamaan regresi berganda dapat dijabarkan sebagai berikut.

1. $a$ merupakan bilangan konstanta, nilai konstanta sebesar $(a=17.297)$ menunjukkan bahwa jika variabel independen pengetahuan dasar ekonomi $\left(\mathrm{X}_{1}\right)$ dan pola konsumsi $\left(\mathrm{X}_{2}\right)$ dianggap konstan maka pola konsumsi santriwan sebesar 17.297.

2. $\beta_{1}$ merupakan koefisien regresi variabel bebas $\mathrm{X}_{1}$ sebesar 0.812 menunjukkan bahwa setiap variabel pengetahuan dasar ekonomi meningkat, maka besarnya pola konsumsi santriwan (Y) akan meningkat sebesar 0.812 dengan mengasumsikan variabel bebas lain konstan.

3. $\beta_{2}$ merupakan koefisien regresi variabel bebas $\mathrm{X}_{2}$ sebesar 0.451 menunjukkan bahwa setiap variabel persepsi lingkungan pondok pesantren meningkat, maka besarnya hasil pola konsumsi santriwan (Y) akan meningkat sebesar 0.451 dengan mengasumsikan variabel bebas lain konstan.

4. $e_{i}$ merupakan faktor lain diluar rancangan penelitian. $e$ merupakan error kesalahan yang terjadi pada perkiraan $\mathrm{Y}$ disebabkan karena masih ada faktor lain selain $\mathrm{X}$ yang mempengaruhi $\mathrm{Y}$ tetapi tidak diperhitungkan

Tabel 9. Sumbangan Efektif

\begin{tabular}{ccccc}
\hline $\begin{array}{c}\text { Vari } \\
\text { abel }\end{array}$ & Beta & $\begin{array}{c}\text { Zero- } \\
\text { order }\end{array}$ & $\begin{array}{l}\text { Persen } \\
\text { tase }\end{array}$ & $\begin{array}{l}\text { Sumbang } \\
\text { an Efektif }\end{array}$ \\
\hline $\mathrm{X}_{1}$ & 0.376 & 0.479 & $100 \%$ & $18 \%$ \\
\hline $\mathrm{X}_{2}$ & 0.477 & 0.558 & $100 \%$ & $26.6 \%$ \\
\hline \multicolumn{5}{c}{ Total } \\
\hline
\end{tabular}

Jadi jumlah sumbangan efektif variabel $\mathrm{X}_{1}$ dan $\mathrm{X}_{2}$ secara simultan terhadap variabel $\mathrm{Y}$ adalah sebesar $44.6 \%$. Hal ini menunjukkan sisanya sebesar $55.4 \%$ dipengaruhi oleh faktor lain di luar variabel $\mathrm{X}_{1}$ dan $\mathrm{X}_{2}$ yang mempengaruhi hasil belajar siswa

\section{Koefisien Determinasi (Uji R Square)}

Berdasarkan pada tabel 4.12 diatas dapat diketahui bahwa $R$ Square sebesar 0.446 atau $44.6 \%$. Hal ini menunjukkan bahwa $44.6 \%$ perubahan variabel (Y) dipengaruhi oleh perubahan variabel $\left(\mathrm{X}_{1}\right)$ dan variabel $\left(\mathrm{X}_{2}\right)$. Sedangkan sisanya sebesar $55.4 \%$ dipengaruhi oleh faktor lain di luar variabel $\mathrm{X}_{1}$ dan $\mathrm{X}_{2}$ yang mempengaruhi pola konsumsi santriwan.

Pengaruh Pengetahuan Dasar Ekonomi Terhadap Pola Konsumsi santriwan IIS MA Pondok Pesantren Nurul Ulum Malang 
Berdasarkan penelitian tentang pengetahuan dasar ekonomi santriwan IIS MA Pondok Pesantren Nurul Ulum Malang menunjukkan bahwa ada pengaruh antara Pengetahuan Dasar Ekonomi Terhadap Pola Konsumsi santriwan IIS MA Pondok Pesantren Nurul Ulum Malang, karena didalam pondok pesantren santriwan tidak hanya dibekali atau diberikan pengajaran tentang ilmu agama saja melainkan tentang ilmu umum seperti pelajaran ekonomi. Pelajaran ekonomi yang mereka dapat didalam pondok pesantren sangat membantu mereka dalam kehidupan sehari hari didalam pembelajaran didalam pondok pesantren. Pengetahuan tentang ilmu ekonomi membuat santriwan memiliki pola konsumsi yang baik atau rasional karena santriwan tersebut dapat membedakan mana kebutuhan dan mana keinginan. Santriwan yang paham dapat mengutamakan kebutuhan daripada keinginan karena apa yang dibutuhkan santriwan tersebut harus dibeli saat itu juga. Santriwan yang mempunyai pemahaman dasar ekonomi dapat membuat keputusan yang tepat untuk melakukan konsumsi karena siswa tersebut sudah menguasai dasar-dasar ekonomi (Haryono, 2012)

Santriwan IIS MA Nurul Ulum Malang yang mempunyai pengetahuan ekonomi yang baik, mereka lebih selektif lagi dalam hal membeli barang dan menyesuaikan kebutuhan sebagai santri. Mereka dapat mengalokasikan uang saku mereka untuk membeli kebutuhan sebagai santri didalam pondok pesantren seperti membeli alat tulis maupun kebutuhan sehari hari. Santriwan yang kurang baik dalam pemahaman ekonomi, mereka cenderung lebih konsumtif, misalnya membeli barang yang saat itu belum dibutuhkan dan mengenyampingkan kebutuhan pokok sebagai santri yang tinggal didalam pondok pesantren.

Berdasarkan hasil penelitian ini sejalan dengan penelitian yang dilakukan oleh Widia Dwiningsari (2016) yang berjudul "Pengaruh Literasi Ekonomi Siswa, Status social ekonomi Orang Tua, dan Konformitas Teman sebaya terhadap Pola konsumsi Siswa Kelas XI IIS SMA Brawijaya Smart School" yang menyatakan bahwa ada pengaruh signifikan antara literasi ekonomi siswa terhadap pola konsumsi siswa. Dapat disimpulkan bahwa ada pengaruh yang signifikan secara parsial antara pengetahuan dasar ekonomi santriwan terhadap pola konsumsi santriwan IIS MA Pondok Pesantren Nurul Ulum Malang. Hal ini mengindikasikan bahwa semakin tinggi tingkat pengetahuan dasar ekonomi santriwan maka semakin baik pola konsumsi santriwan.

\section{Pengaruh Persepsi lingkungan pondok pesantren Terhadap Pola Konsumsi santriwan IIS MA Pondok Pesantren Nurul Ulum Malang}

Berdasarkan penelitian tentang persepsi lingkungan pondok pesantren santriwan IIS MA Pondok Pesantren Nurul Ulum Malang menunjukkan bahwa ada pengaruh antara persepsi lingkungan pondok pesantren tehadap pola konsumsi santriwan IIS MA Pondok Pesantren Nurul Ulum Malang. Pengaruh tersebut dikarenakan didalam pondok pesantren santriwan menilai bahwa di dalam pondok pesantren di ajari kehidupan yang mandiri tidak hanya mengenai pembelajaran tentang ilmu umum didalam kelas melainkan ilmu bagaimana hidup di luar rumah atau jauh dari keluarga. Kemandirian, kedisiplinan serta kehidupan berkelompok didalam pondok pesantren yang diajarkan didalam pondok pesantren menjadi bekal bagi diri santri untuk memutuskan atau menyelesaikan masalah dengan lebih baik khususnya dalam hal ini adalah keputusan yang tepat untuk berkonsumsi. 
Dapat disimpulkan bahwa ada pengaruh yang signifikan secara parsial antara persepsi lingkungan pondok pesantren terhadap pola konsumsi santriwan IIS MA Pondok Pesantren Nurul Ulum Malang. Hal ini mengindikasikan bahwa semakin tinggi tingkat pengetahuan dasar ekonomi santriwan maka semakin baik pola konsumsi santriwan. Hal ini sesuai dengan hasil penelitian Purwati (2011) yaitu status sosial ekonomi orang tua siswa, persepsi siswa atas lingkungannya, dan prestasi belajar ekonomi berpengaruh positif dan signifikan terhadap perilaku konsumsi siswa. Persepsi siswa atas lingkungan mempunyai pengaruh yang lebih besar bila dibanding dengan pengaruh status sosial ekonomi orang tua siswa.

\section{Pengaruh Pengetahuan Dasar Ekonomi dan Persepsi lingkungan pondok pesantren Terhadap Pola Konsumsi santriwan IIS MA Pondok Pesantren Nurul Ulum Malang}

Berdasarkan hasil penelitian antara pengetahuan dasar ekonomi dan persepsi lingkungan pondok pesantren oleh santriwan IIS MA Pondok Pesantren Nurul Ulum Malang menunjukkan bahwa terdapat pengaruh terhadap terhadap pola konsumsi santriwan IIS MA Pondok Pesantren Nurul Ulum Malang. Persepsi lingkungan pondok pesantren lebih dominan menentukan pola konsumsi dibandingkan pengetahuan dasar ekonomi.

Pengaruh ini terjadi karena santri yang tinggal didalam pondok pesantren menilai bahwa didalam pondok pesantren diajarkan tentang kemandirian, kedisiplinan dan juga kehidupan sosial yang langsung dipraktekan didalam kehidupan sehari hari,. Kemandirian diperoleh santri dari bagaimana hidup jauh dari orang tua, kedisiplinan diperoleh dari aturan dan tata tertib didalam pondok pesantren serta kehidupan yang membaur langsung dengan sesama santri, guru atau uztad dan lingkungan masyarakat disekitar pondok.

Pengetahuan dasar ekonomi yang diberikan kepada santri di dalam kelas menambah wawasan santri tentang kehidupan berekonomi khususnya berkonsumsi. Persepsi lingkungan pondok pesantren yang baik serta ditambah wawasan tentang pengetahuan dasar ekonomi membuat santri lebih selektif dan lebih bijak untuk berkonsumsi. Hal ini sesuai dengan pendapat Sina (2012) dalam penelitiannya yang dimuat dalam jurnal Ekonomika-UNY, 8(2): 135-143, dinyatakan bahwa peningkatan literasi ekonomi secara spesifik berdampak positif pada akumulasi aset, deakumulasi utang, proteksi, akumulasi menabung dan kecermatan mengelola pengeluaran.

\section{KESIMPULAN}

Berdasarkan hasil penelitian yang telah dilakukan mengenai pengaruh pengetahuan dasar ekonomi dan persepsi lingkungan pondok pesantren terhadap pola konsumsi santriwan IIS MA Pondok Pesantren Nururul Ulum, maka dapat disimpulkan sebagai berikut: 1) Secara parsial pengetahuan dasar ekonomi berpengaruh signifikan terhadap pola konsumsi santriwan IIS MA Pondok Pesantren Nurul Ulum Malang; 2) Secara parsial persepsi lingku-ngan pondok pesantren berpengaruh signifikan terhadap pola konsumsi santriwan IIS MA Pondok Pesantren Nurul Ulum Malang. Secara simultan 
pengetahuan dasar ekonomi dan persepsi lingkungan pondok pesantren berpengaruh signifikan terhadap pola konsumsi santriwan IIS MA Pondok Pesantren Nurul Ulum Malang

Berdasarkan beberapa kesimpulan di atas, maka saran yang dapat peneliti berikan adalah sebagai berikut: 1) Bagi Kepala MA Pondok Pesantren Nurul Ulum: Kepala MA Pondok Pesantren Nurul Ulum untuk pembertahan dihimbau untuk mempertahankan dan terus meningkatkan pengetahuan dasar ekonomi santriwan agar dapat memanfaatkan uang saku yang diberikan orangtua wali santriwan dimanfaatkan dengan baik oleh santriwan ketika tinggal didalam pondok pesantren. Selain itu mempertahankan dan memperbaiki persepsi lingkungan pondok pesantren yang baik melalui pembiasaan, pengajaran, pengarahan dan keteladanan; 2) Bagi Santri: Melihat hasil penelitian, hendaknya santriwan lebih meningkatkan pengetahuan dasar ekonomi sebagai pertimbangan atau bekal dalam hal yang bersangkutan dengan kegiatan ekonomi khususnya berkonsumsi setiap hari dan memanfaatkan sebaik baiknya persepsi lingkungan pondok pesantren; 3) Bagi Peneliti Selanjutnya: Peneliti selanjutnya diharapkan untuk lebih mengembanfkan dan dapat memperluas dengan variabel lain yang lebih berpengaruh terhadap pola konsumsi atau variabel yang lebih berhubungan dengan kepesantrenan

\section{DAFTAR RUJUKAN}

Dhofier, Zamakhsari, (2015) Tradisi Pesantren, Studi Pandangan Hidup Kyai dan Visinya Mengenai Masa Depan Indonesia. Jakarata: LP3S

Dwiningsari, Widia. (2016). Pengaruh Literasi Ekonomi Siswa, Status social ekonomi Orang Tua, dan Konformitas Teman sebaya terhadap Pola konsumsi Siswa Kelas XI IIS SMA Brawijaya Smart School. Skripsi tidak diterbitkan. Malang: FE UM

Haryono, Agung. (2012) Pengembangan Model-Model Pembelajaran Berbasis Economic Literacy Siswa SMA. Jurnal Penelitian Pendidikan. 1. (Online):1:11, (http://jpk.lemlit.um.ac.id), diakses 7 november 2016

Mankiw, N. Georgy. (2012) Pengantar Ekonomi Mikro. Jakarta: Salemba Empat

PISA (2012) Financial Literacy Assessment Framework. Diperoleh dari http://www.oecd.org/pisa/pisaproducts/469 62580.pdf.

Purwati, Ana. (2011). Pengaruh Status Sosial Ekonomi Orang Tua, Prersepsi atas Lingkungan dan Prestasi Belajar Ekonomi Terhadap Perilaku Konsumsi, Jurnal Ekonomi Bisnis, Th. 16, No. 1, 1-6, Maret 2011

Rosydi, suherman (2006) Pengantar Terori Ekonomi.: Pendekatan Kepada Teori Mikro. Jakarta: Erlangga.

Sina, Peter Garlans (2012) Analisis Literasi Ekonomi. Jurnal Ekonomika, (Online), 8(2): 135-143, (http://journal.uny.ac.id) diakses 7 november 2012

Universitas Negeri Malang (2010) Pedoman Penulisan Karya Imiah: Skripsi, Thesis, Disertasi, Artikel, Makalah, Laporan Penelitian. Edisi Keempat. Malang: Universitas 